\title{
Test of Redfield's model for oxygen-nutrient relationships using regression analysis ${ }^{2}$
}

\section{Saul Alvarez-Borrego}

Instituto de Investigaciones Oceanologicas, Universidad Autonoma de Baja California, Ensenada, Mexico

\section{Donald Guthrie}

Department of Statistics, Oregon State University, Corvallis 97331

\section{Charles H. Culberson and P. Kilho Park}

School of Oceanography, Oregon State University

\begin{abstract}
Multiple regression analysis was applied to oxygen, phosphate, and nitrate data from stations in the Atlantic and Pacific Oceans. The $95 \%$ confidence intervals for $\triangle O_{\lrcorner}: \triangle P_{k}$ and $\Delta \mathrm{O}_{2}: \triangle \mathrm{NO}_{3}$ ratios were consistent with Redfield's model. Thus, the variation of $\mathrm{O}_{2}-\mathrm{PO}_{4}$ and $\mathrm{O}_{2}-\mathrm{NO}$. slopes with deptlı, latitude, and time is due to mixing betwcen different water types with different preformed portions of oxygen, phosphate, and nitrate.
\end{abstract}

Redfield (1934, 1942; Redfield et al. 1963) proposed a relation between the concentrations of dissolved oxygen, carbon dioxide, nitrate, and phosphate in scawater based on the average chemical composition of plankton (Fleming 1941). This relation predicts that the ratio of oxygen consumption to nutrient production by biological oxidation is constant and can be represented by the equation

$$
\begin{aligned}
& \left(\mathrm{CH}_{2} \mathrm{O}\right)_{100}\left(\mathrm{NH}_{3}\right)_{1 ;} \mathrm{H}_{3} \mathrm{PO}_{4}+138 \mathrm{O}_{2}= \\
& 106 \mathrm{CO}+122 \mathrm{H}_{2} \mathrm{O}+16 \mathrm{HNO}_{3}+\mathrm{H}_{3} \mathrm{PO}_{4} .
\end{aligned}
$$

$\left(\mathrm{CH}_{2} \mathrm{O}\right)_{106}\left(\mathrm{NH}_{3}\right)_{16} \mathrm{H}_{3} \mathrm{PO}_{4}$ is a hypothetical organic molecule containing carbon, nitrogen, and phosphorus in the ratio in which they occur in plankton. Equation 1 predicts that the consumption of 276 oxygen atoms results in the production of 106 carbon atoms, 16 nitrogen atoms, and 1 phosphorus atom.

Theoretically, the best way to test Redficld's model is to plot oxygen consumption (apparent oxygen utilization: AOU) ver-

${ }^{1}$ This work was supported by National Science Foundation grants CX-28167 and GA-12113 and Office of Naval Research contract N00014-67-A0369-0007 under project NR 083-102. The "Consejo Nacional de Ciercia y Tccnologia" of Mexico supported the work of S. Alvarez-Borrego in partial fulfillment of the requirements for the Ph.D. at Oregon State University. sus the increase in concentration of a nutrient arising from this biological oxidation; at present however, changes in nutrient cont centrations due to biological oxidation cannot be calculated independently without the use of this nodel. The purpose of our work was to test Redfield's model for the $\mathrm{O}_{2}-\mathrm{PO}_{4}$ and $\mathrm{O}_{2}-\mathrm{NO}_{3}$ relationships by applying multiple regression analysis to field data.

\section{Data sources}

We used hydrographic data from the following cruises: YALOC-66 (Barstow et al. 1968), SCORPIO (Scripps Inst. Oceanogr. Data Rep. Ref. 69-15, Woods Hole Oceanogr. Inst. Data Rep. Ref. 69-56), SOUTHERN CROSS (Horibe 1970), and from GEOSECS intercalibration stations in the Atlantic (Spencer 1970) and Pacific (GOGO-I unpublished data). Station positions are shown in Fig. 1. Nutrient measurements during GOGO-I were made by a Technicon AutoAnalyzer with a precision of $\pm 1 \%$ or better. Nutrient determinations on all other cruises were made by manual methods. The precision of nutrient analyses is not reported for YALOC-66 and SCORPIO expeditions. For the SOUTHERN CROSS cruise, the estimated precision was $\pm 4 \%$ for nitrate and $\pm 3 \%$ for phosphate (IIoribe 1970). 


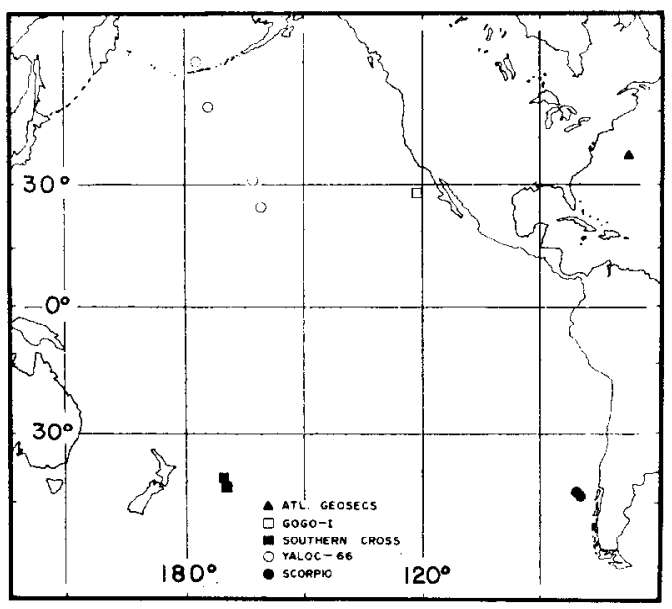

Fig. I. Locations of the hydrographic stations used in this study.

\section{Discussion}

The regeneration of nitrate in seawater is more complicated than that of phosphate. Nitrogen is released from organic substances as ammonia and subsequently oxidized to nitrite, and then to nitrate (Redfield et al. 1963). Ammonia and nitrite are not ordinarily found in significant quantities below the photosynthetic zone in the deep sea, and we will assume that all nitrogen derived from biological oxidation is in the form of nitrate.

When $\mathrm{O}_{2}$ is expressed in $\mathrm{ml}$ liter ${ }^{-1}$, and $\mathrm{PO}_{4}$ and $\mathrm{NO}_{3}$ are in $\mu \mathrm{M}$, the ratios proposed by Redfield et al. (1963) are $\mathrm{O}_{2}$ : $\mathrm{PO}_{4}=-3.1, \mathrm{O}_{2}: \mathrm{NO}_{3}=-0.19$. From Redfield et al. (1963),

$$
\begin{gathered}
\mathrm{AOU}=\mathrm{O}_{2}{ }^{\prime}-\mathrm{O}_{2}, \\
\mathrm{PO}_{4}=\mathrm{PO}_{4(\mathrm{ux})}+\mathrm{PO}_{4(\mathrm{p})}, \\
\mathrm{PO}_{4(0 \mathrm{x})}=(\mathrm{AOU}) / 3.1, \\
\mathrm{NO}_{3}=\mathrm{NO}_{3(\mathrm{x})}+\mathrm{NO}_{3(1)},
\end{gathered}
$$

and

$$
\mathrm{NO}_{3(\mathrm{ax})}=(\mathrm{AOU}) / 0.19,
$$

where $\mathrm{O}_{2}{ }^{\prime}$ is the calculated concentration of dissolved oxygen at saturation with a wet atmosphere at the potential temperature of the sample; $\mathrm{PO}_{4(\alpha x)}$ and $\mathrm{NO}_{3(\alpha x)}$ are the phosphate and nitrate released by biological oxidation; and $\mathrm{PO}_{4(p)}$ and $\mathrm{NO}_{3(p)}$ are the preformed phosphate and nitrate. Rearranging Eq. 2-6 yields

$$
\mathrm{O}_{2}=-3.1 \mathrm{PO}_{4}+\left[\mathrm{O}_{2}^{\prime}+3.1 \mathrm{PO}_{4(\mathrm{n})}\right] \text {, }
$$

and

$$
\mathrm{O}_{2}=-0.19 \mathrm{NO}_{3}+\left[\mathrm{O}_{2}^{\prime}+0.19 \mathrm{NO}_{3(\mathrm{p})}\right] \text {. }
$$

From Eq. 7 and 8 we see that if Redfield's model is correct, any variation of the $\mathrm{O}_{2}-$ $\mathrm{PO}_{4}$ and $\mathrm{O},-\mathrm{NO}_{3}$ slopes with location, depth, and time is due to mixing between water types with different values of preformed $\mathrm{O}_{2}\left(\mathrm{O}_{2}{ }^{\prime}\right), \mathrm{PO}_{4}$, and $\mathrm{NO}_{3}$.

Test of Redfield's model by regression analysis-One way to test Redfield's model is by using regression analysis on field data. If we regress $\mathrm{O}_{2}$ on $\mathrm{PO}_{4}$, temperature and salinity, the temperature or salinity terms may represent the conservative fraction of phosphate and oxygen, namely $\mathrm{O}_{2}^{\prime}+3.1$ $\mathrm{PO}_{4(\mathrm{p})}$, so that the $\mathrm{PO}_{4}$ term represents only the nonconservative fractions. The same type of approach can be used for the $\mathrm{O}-\mathrm{NO}_{3}$ relationship.

Ben-Yaakov (1971) applied regression analysis to $\mathrm{\Sigma} \mathrm{CO}_{2}, \mathrm{O}_{2}$, total alkalinity, salinity, $S$, and temperature data. He showed that, when dealing with a water mass which results from the mixing of $n$ water types, at least $n-1$ conservative parameters are needed in the regression equation.

We will first use the regression analysis to test Redfield's model for the $\Delta \mathrm{O}_{2}: \Delta \mathrm{PO}_{4}$ ratio, and then apply the same procedure to the $\Delta \mathrm{O}_{2}: \Delta \mathrm{NO}_{3}$ ratio. To test the hypothesis that the $\Delta \mathrm{O}_{2}: \Delta \mathrm{PO}_{4}$ ratio is equal to -3.1 , the regression equation

$$
\mathrm{O}_{2}=a_{0}+a_{1} \mathrm{PO}_{4}+a_{2} \theta+\mathrm{O}_{2 \text { (res) }}
$$

was applied to the data, where $\mathrm{O}_{2 \text { (res) }}$ are the $\mathrm{O}_{2}$ residuals after regression of $\mathrm{O}_{2}$ on $\mathrm{PO}_{4}$ and potential temperature $(\theta) ; a_{0}, a_{1}$, and $a_{2}$ are constant regression coefficients. $a_{1}$ equals $\Delta \mathrm{O}_{2}: \Delta \mathrm{PO}_{4}$. Potential temperature is used to eliminate the effect of adiabatic heating; it is preferred to $S$ because $\mathrm{O}_{2}^{\prime}$ depends more on temperature than on S.

It may seem that to apply Eq. 9 to field data we must choose a portion of the water column where no more than two water types are mixed, since we only have one conservative variable in the equation. But by comparing Eq. 7 and 9 we see that the 

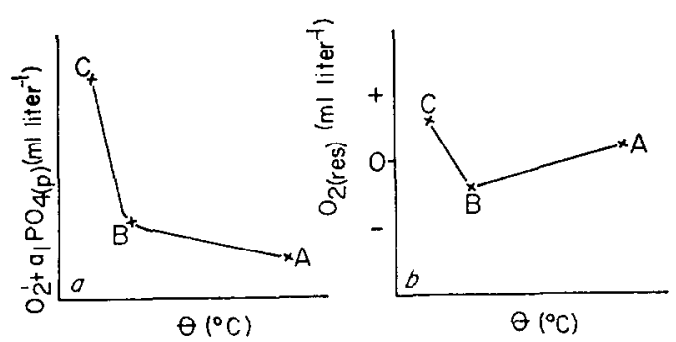

Fig. 2. $\mathrm{O}_{2}^{\prime}+a_{1} \mathrm{PO}_{4(n)}$ versus $\theta-\mathrm{a} ; \mathrm{O}_{2(r \mathrm{r})}$ versus $\theta-\mathbf{b}$, of a hypothetical station.

only condition necessary for the proper application of 9 is that the conservative quantity $\mathrm{O}_{2}^{\prime}+a_{1} \mathrm{PO}_{4(n)}$ be a linear function of $\theta$. That is

$$
\mathrm{O}_{2}^{\prime}+a_{1} \mathrm{PO}_{4(\mathrm{p})}=a_{0}+a_{2} \theta .
$$

This means that Eq. 9 must be applied to data from a portion of the water column where a diagram of $\mathrm{O}_{2}{ }^{\prime}+a_{1} \mathrm{PO}_{4(\mathrm{p})}$ versus $\theta$ can detect only two-point mixing.

If Eq. 9 is applied to the proper portion of the water column, a plot of $\mathrm{O}_{2 \text { (res) }}$ versus $\theta$ should be completely random, becanse $\mathrm{O}_{2(\mathrm{res})}$ should result from only the random errors in the measurements of $\mathrm{O}_{2}, \mathrm{PO}_{4}$, and $\theta$. Thus, if we apply 9 to the whole water column and plot $O_{2}$ (res) versus $\theta$, the pattern shown by the diagram, if any, will give us an indication of how to separate the water column into suitable portions.

Suppose we have data from the whole water column of a certain station, and it yields the $\mathrm{O}_{2}{ }^{\prime}+a_{1} \mathrm{PO}_{4(p)}$ versus $\theta$ diagram similar to the one shown in Fig. $2 a$ where three water types, $A, B$, and $C$, have been detected. Since $\mathrm{O}_{2}{ }^{\prime}+a_{1} \mathrm{PO}_{4(\mathrm{p})}$ is not a linear function of $\theta$, a plot of $\mathrm{O}$ (res) versus $\theta$ would generate a diagram as shown in Fig. 2b. Each minimum and maximum in the $\mathrm{O}_{2(\mathrm{res})}$ versus $\theta$ diagram represents a different water type. This procedure was applied to data from station HAH30 of YALOC-66 $\left(30^{\circ} 55.4^{\prime} \mathrm{N}, 162^{\circ} 37.4^{\prime} \mathrm{W}\right.$ ) (Barstow et al. 1968). This station was chosen because samples were taken from $49 \mathrm{dif}$ ferent depths. Most published data contain no more than 30 observations per station. The number of observations is important because the standard errors of the

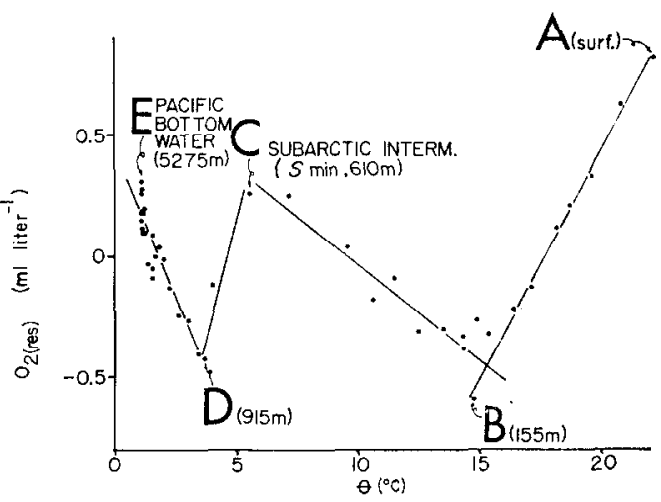

Fig. 3. $\mathrm{O}_{2(\text { res })}$ versus $\theta$ diagram for the whole water column of station $\mathrm{HAH} 30\left(30^{\circ} 55.4^{\prime} \mathrm{N}, 162^{\circ}\right.$ $\left.37.4^{\prime} \mathrm{W}\right), \mathrm{A}, \mathrm{B}, \mathrm{C}, \mathrm{D}$, and $\mathrm{E}$ denote water types.

regression coefficients decrease as the degrees of freedom increase. Multiple linear regression analysis is a least square fit to the given data. The fitting was accomplished by a computer program (SIPS: Oregon State Univ. Dep. Statistics). For each coefficient of the following regression cquations, $95 \%$ confidence intervals are given.

The results are as follows. Regressing O. on $\mathrm{PO}_{4}$ and $\theta$ for the whole water column, $0-5,275 \mathrm{~m}$, we find the regression equations

$$
\begin{aligned}
& \text { with } \mathrm{PO}_{4} \text { only: } \\
& \qquad \begin{aligned}
\mathrm{O}_{2}= & (5.79 \pm 0.36) \\
& -(1.27 \pm 0.17) \mathrm{PO}_{4} ;
\end{aligned}
\end{aligned}
$$

with $\mathrm{PO}_{+}$and $\theta$ :

$$
\begin{aligned}
\mathrm{O}_{2 .}= & (10.65 \pm 0.78)-(0.27 \pm 0.04) \theta \\
& -(2.85 \pm 0.26) \mathrm{PO}_{4} .
\end{aligned}
$$

Equation 12 has a coefficient of determination $R^{2}=0.969$.

Figure 3 shows a definite dependency of $\mathrm{O}_{2(\mathrm{res})}$ on $\theta$. Since the $\mathrm{O}_{2}$ versus $\theta$ diagram is a smooth curve (Fig. 4), the pattern shown in Fig. 3 is due to differences in $\mathrm{PO}_{4(1)}$ between different water types. In Fig. 3, $\mathrm{A}$ is surface water, $\mathrm{C}$ is Subarctic Intermediate Water with a salinity minimum, $\mathrm{D}$ coincides almost with the $\mathrm{O}_{2}$ minimum, $\mathrm{E}$ is Pacific Bottom Water. The $\theta-S$ diagram (Fig. 5) does not show B and D distinctly, but suggests their presence be- 
Alvarez-Borrego et al.



Fig. 4. $\mathrm{O}_{2}^{\prime}$ versus $\theta$ diagram for the whole water column of station HAH30.

cause the $\theta-S$ diagram is not linear in their vicinity. For Antarctic Intermediate $\mathrm{Wa}$ ter, Reid (1965) chose the surface of thermosteric anomaly $\left(\delta_{t}\right)$ equal to $80 \mathrm{cl} \mathrm{ton}^{-1}$, $\sigma_{t}=27.28$. Water D (Fig. 3) has a $\sigma_{t}$ of 27.32 .

The confidence interval for the $\mathrm{PO}_{4}$ re-

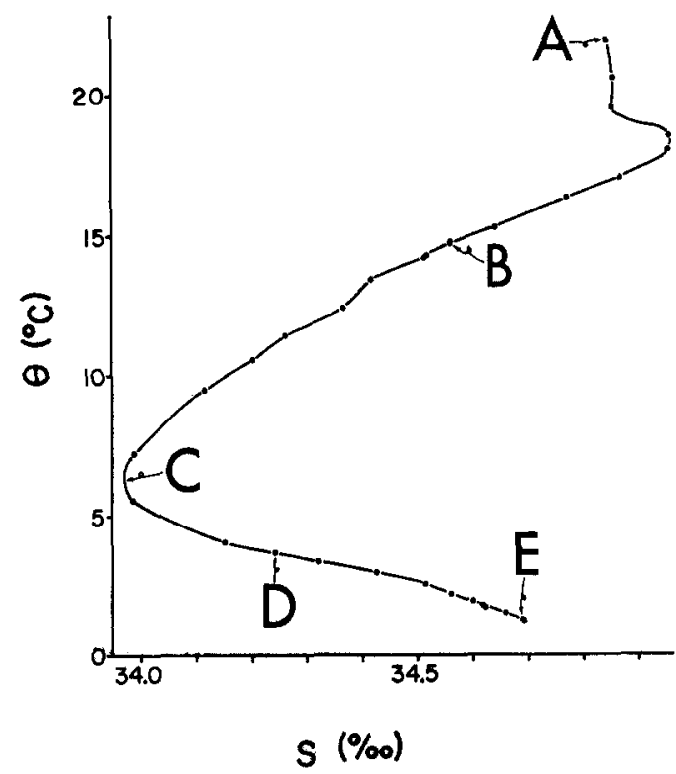

Fig. 5. $\theta-S$ diagram for station HAH30 $\left(30^{\circ}\right.$ $\left.55.4^{\prime} \mathrm{N}, 162^{\circ} 37.4^{\prime} \mathrm{W}\right)$. A, B, C, D, and $\mathrm{E}$ denote same water types shown in Fig. 3 .

gression coefficient, $-(2.85 \pm 0.26)$, in Eq. 12 is consistent with Redfield's model. This agreement is fortuitous since the plot of

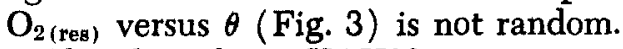

The data from $\mathrm{HAH} 30$ was separated into three sets: $A$ to $B, B$ to $C$, and $D$ to $E$. Between C and D (Fig. 3) there is only one data point so no regression was applied to that portion of the water column.

Table 1. Regression equations of $\mathrm{O}_{1}$ on $\mathrm{PO}_{4}$ and $\theta$ for different portions of the water column of station $\mathrm{HAH} 30$.

\begin{tabular}{llr}
\hline $\begin{array}{l}\text { Portion of the } \\
\text { water column }\end{array} \quad$ Regression equations (showing 95\% confidence intervals) & $\begin{array}{c}\text { Equation } \\
\text { number }\end{array}$ \\
\hline $\mathrm{A}-\mathrm{B}$ & with $\mathrm{PO}_{4}$ only: $\mathrm{O}_{2}=(5.54 \pm 0.15)-(1.12 \pm 0.80) \mathrm{PO}_{4}$ & 13 \\
$(0-155 \mathrm{~m})$ & with $\mathrm{PO}_{4}$ and $\theta: \mathrm{O}_{2}=(7.08 \pm 0.60)-(0.07 \pm 0.03) \theta-(2.50 \pm 0.64) \mathrm{PO}$ & 14 \\
\hline $\mathrm{B}-\mathrm{C}$ & with $\mathrm{PO}_{4}$ only: $\mathrm{O}_{2}=(5.71 \pm 0.24)-(1.20 \pm 0.20) \mathrm{PO}_{4}$ & 15 \\
$(155-610 \mathrm{~m})$ & with $\mathrm{PO}_{4}$ and $\theta: \mathrm{O}_{2}=(10.91 \pm 1.84)-(0.32 \pm 0.12) \theta-(2.71 \pm 0.54) \mathrm{PO}$ & 16 \\
\hline $\mathrm{D}-\mathrm{E}$ & with $\mathrm{PO}_{4}$ only: $\mathrm{O}_{2}=(14.18 \pm 0.70)-(4.3 \pm 0.26) \mathrm{PO}$ & 17 \\
$(915-5,275)$ & with $\mathrm{PO}_{4}$ and $\theta: \mathrm{O}_{2}=(11.27 \pm 0.78)-(0.49 \pm 0.12) \theta-(2.93 \pm 0.36) \mathrm{PO}$ & 18 \\
\hline
\end{tabular}




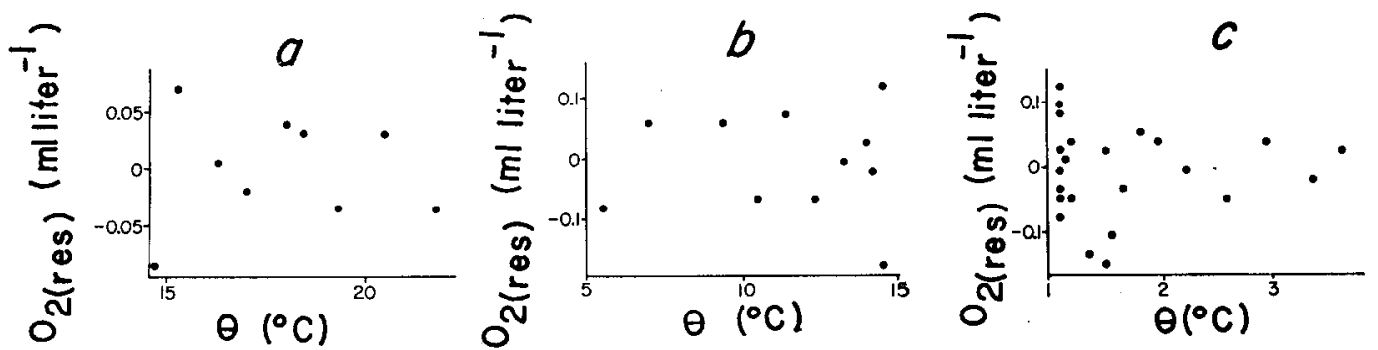

Fig. 6. $\mathrm{O}_{2(\mathrm{res})}$ versus $\theta$ diagrams for portions of the water column. $\mathrm{a}-0$ to $155 \mathrm{~m}$; $\mathrm{b}-155$ to $610 \mathrm{~m} ; \mathrm{c}-915$ to $5,275 \mathrm{~m}$, station HAH 30 .

The results of the regressions for this station are shown in Table 1.

Equations 14, 16, and 18 (given in Table 1) have coefficients of determination, $R^{2}$, equal to $0.915,0.988$, and 0.996 .

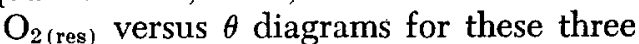
sets of data show no particular trend (Fig. 6 ). This indicates that $\mathrm{O}_{2 \text { (res) }}$ results only from random errors in the $\mathrm{O}_{2}, \mathrm{PQ}_{4}$, and $\theta$ data, and that Eq. 14, 16, and 18 properly describe the data.

The $\mathrm{PO}_{4}$ regression coefficients of Eq. 13, 15, and 17 (Table 1) are the least squares slopes we obtained by plotting $\mathrm{O}_{2}$ versus $\mathrm{PO}_{4}$ directly. Before $\theta$ is added to the regression equations, the $\mathrm{PO}_{4}$ regression coefficients for $\mathrm{A}-\mathrm{B}$ and $\mathrm{B}-\mathrm{C}$ are smaller than the value predicted by Redfield's model, and those for D-E greater. After adding $\theta$ to the equations, the phosphate regression coefficients approach the predicted value, -3.1 , more closely.

To test the hypothesis that the $\Delta \mathrm{O}_{2}$ : $\Delta \mathrm{NO}_{3}$ ratio equals -0.19 , the regression equation

$$
\mathrm{O}_{2}=b_{0}+b_{1} \mathrm{NO}_{3}+b_{2} \theta+\mathrm{O}_{2\left(\mathrm{res}^{\prime}\right)}
$$

was applied to the data, where $\mathrm{O}_{2 \text { (res') }}$ are the $\mathrm{O}_{2}$ residuals after regression of $\mathrm{O}_{2}$ on $\mathrm{NO}_{3}$ and $\theta ; b_{0}, b_{1}$, and $b_{2}$ are constant regression coefficients, and $b_{1}$ equals $\Delta \mathrm{O}_{22}$ : $\triangle \mathrm{NO}_{3}$.

Applying Eq. 19 to data from HAH30 (no $\mathrm{NO}_{3}$ data for upper $35 \mathrm{~m}$ ) we obtained the following results

with $\mathrm{NO}_{3}$ only:

$$
\begin{aligned}
\mathrm{O}_{2}= & (5.71 \pm 0.42) \\
& -(0.889 \pm 0.014) \mathrm{NO}_{3} ;
\end{aligned}
$$

with $\mathrm{NO}_{3}$ and $\theta$ :

$$
\begin{gathered}
\mathrm{O}_{2}=(10.98 \pm 1.08)-(0.33 \pm 0.12) \theta \\
-(0.21 \pm 0.02) \mathrm{NO}_{3} .
\end{gathered}
$$

Equation 21 has a coefficient of determination $R^{2}=0.953$.

Figure 7 shows a definite dependency of $\mathrm{O}_{2 \text { (res') }}$ on $\theta$. It also shows very clearly the Subarctic Intermediate Water and water type D shown in Fig. 3. Below 3,725 m values for $\mathrm{O}_{2 \text { (res') }}$ vary randomly. The data points scatter more in Fig. 7 than in Fig. 3 because $\mathrm{NO}_{3}$ data are not as precise as $\mathrm{PO}_{4}$ data from this station. During YALOC-66, $\mathrm{PO}_{4}$ samples were analyzed immediately while $\mathrm{NO}_{3}$ samples were frozen and analyzed ashore (Barstow et al. 1968).

The confidence interval for the $\mathrm{NO}_{3}$ regression coefficient of Eq. 22 (Table 2), -0.19 to -0.23 , is consistent with Redfield's model-a fortuitous agreement since the plot of $\mathrm{O}_{2 \text { (res') }}$ versus $\theta$ (Fig. 7) is not ran-

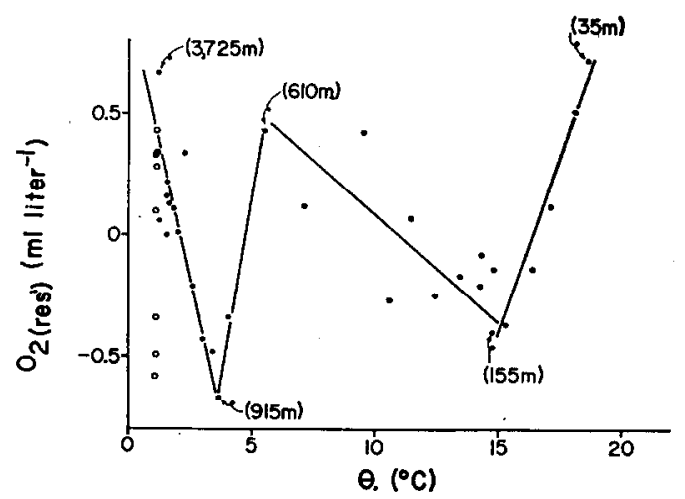

Fig. 7. $\mathrm{O}_{2\left(r e \mathbf{s}^{\prime}\right)}$ versus $\theta$ diagram for the whole water column of station HAH30. Open circles represent data from below $3,725 \mathrm{~m}$. 



Fig. 8. $\mathrm{O}_{2(r e s,)}$ versus $\theta$ diagrams for portions of the water column. a-155 to $610 \mathrm{~m} ; \mathrm{b}-915$ to $3,725 \mathrm{~m}$, station HAH30.

dom. To test Redfield's model we divided the $\mathrm{NO}_{3}$ data into two sets, 155 to $610 \mathrm{~m}$ and 915 to $3,725 \mathrm{~m}$. The regression for the $35-155-\mathrm{m}$ depth range was not significant as there are only six data points for that portion of the water column (Fig. 7). The results of the regressions for this station are shown as Eq. $22-25$ in Table 2. Equations 23 and 25 have coefficients of determination, $R^{2}$, equal to 0.966 and 0.978 .

The $\mathrm{O}_{2\left(\text { res }^{\prime}\right)}$ versus $\theta$ diagrams for these two sets of data are random (Fig. 8). This indicates that $\mathrm{O}_{2 \text { (res') }}$ result only from random errors of $\mathrm{O}_{2}, \mathrm{NO}_{3}$, and $\theta$ data, and that Eq. 23 and 25 properly describe the data. The $\mathrm{NO}_{3}$ regression coefficients of 23 and 25 are consistent with Redfield's model.

Equations 9 and 19 were applied to data from other stations to study the effect of geographic location. The results are shown in Tables 3 and 4 . There are no $\mathrm{NO}_{3}$ data for station HAH52 (Barstow et al. 1968). For the Atlantic GEOSECS station, the Scripps' O.2 data were used (Spencer 1970). Regression equations for those without the $\theta$ term are given in Tables 3 and 4 for comparison of $\mathrm{O}_{2}-\mathrm{PO}_{4}$ and $\mathrm{O}_{2}-\mathrm{NO}_{3}$ slopes before and after the mixing effect is extracted.

The precision of the regression coefficients depends on the random errors of the $\mathrm{O}_{2}, \mathrm{PO}_{4}, \mathrm{NO}_{3}$, and $\theta$ measurements, the range of these properties, and the degrees of freedom of the residuals. Poor precision does not necessarily mean bad field data. Tables 3 and 4 show that in some cases the residuals had only $3 \mathrm{df}$ : with $3 \mathrm{df}$ the value for $t_{(0.025)}$ is 3.18. Some regions of the water column were not tabulated in Tables 3 and 4 , because either the $\mathrm{O}_{2}, \mathrm{PO}_{4}$, and $\mathrm{NO}_{3}$ ranges were too small or there were not enough data points to apply the regression analysis.

Table 2. Regression equations of $\mathrm{O}_{2}$ on NO, and $\theta$ for different portions of the water column of station $\mathrm{HAH} 30$.

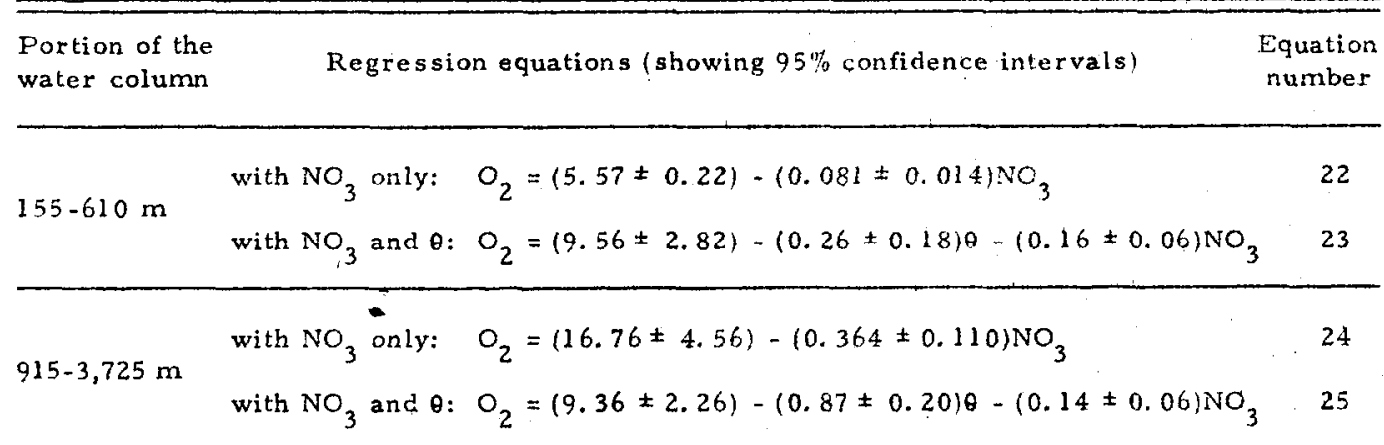




\section{Test of Redfield's model}

Table 3. Regression equations of $\mathrm{O}_{2}$ on $\mathrm{PO}_{4}$ and $\theta$, on $\mathrm{PO}_{4}$ and $\mathrm{S}$, on $\mathrm{NO}_{3}$ and $\theta$, and on $\mathrm{NO}_{5}$ and S. The confidence intervals are at the $95 \%$ confidence level. Stations HAH52, AAH2, and SCORPIO 71 and 72 .

\begin{tabular}{|c|c|c|c|c|}
\hline Station & \begin{tabular}{|c|} 
Depth $x$ ang \\
(ineters) \\
\end{tabular} & Regression eglations (showing $95 \%$ confidence intcrvalis) & $R^{2}$ & $n-p-1$ \\
\hline \multirow[t]{2}{*}{$\begin{array}{l}\text { HAH52 } \\
\left(45^{\circ} 52.8^{\prime} N\right. \\
\left.174^{\circ} 2.3^{\prime} W\right)\end{array}$} & $125-405$ & $\begin{array}{l}\text { with } \mathrm{PO}_{4} \text { only: } \mathrm{O}_{2}=(9.90 \pm 0.39)-(2.78 \pm 0.20) \mathrm{PO}_{4} \\
\text { with } \mathrm{PO}_{4} \& \theta: \mathrm{O}_{2}=(14.02 \pm 3.91)-(3.49 \pm 0.58) \mathrm{PO}_{4}-(0.50 \pm 0.48) \theta\end{array}$ & 0.999 & $\begin{array}{l}4 \\
3\end{array}$ \\
\hline & $405-1765$ & $\begin{array}{l}\text { with } \mathrm{PO}_{4} \text { only: } \mathrm{O}_{2}=(12.54 \pm 2.02)-(3.75 \pm 0.66) \mathrm{PO}_{4} \\
\text { with } \mathrm{PO}_{4} \& \theta: \mathrm{O}_{2}=(13.2 \pm \pm 7.67)-(3.92 \pm 1.95) \mathrm{PO}_{4}-(0.05 \pm 0.59) 9\end{array}$ & $\begin{array}{l}0.978 \\
0.979\end{array}$ & $\begin{array}{l}5 \\
+\end{array}$ \\
\hline \multirow{4}{*}{$\begin{array}{l}\mathrm{AAH2} \\
\left(52^{\circ} 56.1^{\prime} \mathrm{N}\right. \\
\left.179^{\circ} 55^{\prime} \mathrm{W}\right)\end{array}$} & $75-300$ & $\begin{array}{l}\text { with } \mathrm{PO}_{4} \text { only: } \mathrm{O}_{2}=(22.87 \pm 0.90)-(7.05 \pm 0.35) \mathrm{PO}_{4} \\
\text { with } \mathrm{PO}_{4} \text { \& } \mathrm{S}: O_{2}=(186 \pm 96)-(2.9 \pm 2.6) \mathrm{PO}_{4}-(5.2 \pm 3.1 \mathrm{sS}\end{array}$ & 0.999 & 6 \\
\hline & $360-1020$ & $\begin{array}{l}\text { with } \mathrm{PO}_{4} \text { only: } \mathrm{O}_{2}=(24.4 \pm 6.4)-(7.4 \pm 2.0) \mathrm{PO}_{4} \\
\text { with } \mathrm{PO}_{4} \text { \&S: } \mathrm{O}_{2}=(74.4 \pm 23.5)-(3.3 \pm 2.2) \mathrm{PO}_{4}-(1.85 \pm 0.46) \mathrm{S}\end{array}$ & 0.985 & $\begin{array}{l}7 \\
6\end{array}$ \\
\hline & $1215-3200$ & $\begin{array}{l}\text { with } \mathrm{PO}_{4} \text { only: } O_{2}=(20.33 \pm 2.04)-(6.15 \pm 0.66) \mathrm{PO}_{4} \\
\text { with } \mathrm{PO}_{4} \times \mathrm{S}: \mathrm{O}_{2}=-(74.9 \pm 50.8)-\left(4.21 \pm 1.1+1 \mathrm{PO}_{4}+(2.58 \pm 1.281 \mathrm{~s}\right.\end{array}$ & 0.987 & $\begin{array}{l}11 \\
10\end{array}$ \\
\hline & $515-3500$ & $\begin{array}{l}\text { with } \mathrm{NO}_{3} \text { only: } O_{2}=(14.03 \pm 2.06)-\left(0.297 \pm 0.0461 \mathrm{NO}_{3}\right. \\
\text { with } \mathrm{NO}_{3} \mathrm{KS}: \mathrm{O}_{2}=-(40.2 \pm 36.7)-(0.224 \pm 0.060) \mathrm{NO}_{3}+(1.5 \pm 1.01 \mathrm{~S}\end{array}$ & 0.961 & 12 \\
\hline \multirow{2}{*}{$\begin{array}{l}\text { SCOR PIO } \\
71 * 72 \\
\text { (off Chile) }\end{array}$} & $90-865$ & $\begin{array}{l}\text { with } \mathrm{PO}_{4} \text { only: } O_{2}=(6.88 \pm 1.06)-(0.82 \pm 0.62) \mathrm{PO}_{4} \\
\text { with } \mathrm{PO}_{4} \& \theta: O_{2}=(13.80 \pm 0.70)-(3.12 \pm 0.26) \mathrm{PO}_{4}-(0.45 \pm 0.04) \theta\end{array}$ & 0.962 & 24 \\
\hline & $80-840$ & $\begin{array}{l}\text { with } \mathrm{NO}_{3} \text { only: } \mathrm{O}_{2}=(6.49 \pm 0.92)-(0.04 \pm 0.04) \mathrm{NO}_{3} \\
\text { with } \mathrm{NO}_{3} \& \theta: \mathrm{O}_{2}=(15.91 \pm 1.48)-\left(0.26 \pm 0.04 \mathrm{NO}_{3}-10.62 \pm 0.10\right) \theta\end{array}$ & 0.902 & $\begin{array}{l}24 \\
23\end{array}$ \\
\hline
\end{tabular}

*n-p-l arc the residual degrees of freedom, $n$ is the number of observations and $p$ is the number of independent variables alrcady in the regression equation.

Table 4. Regression equations of $\mathrm{O}_{2}$ on $\mathrm{PO}_{4}$ and $\theta$, and on NOs and $\theta$. The confidence intervals are at the $95 \%$ confidence level. North Pacific and North Atlantic GEOSECS intercalibration stations.

\begin{tabular}{|c|c|c|c|c|}
\hline Station & $\begin{array}{l}\text { Mpth range } \\
\text { meters }\end{array}$ & Regression equations (showing $95^{\circ} \circ$ conficlence intervals) & $R^{2}$ & $n-1, \cdot 1=$ \\
\hline \multirow{4}{*}{$\begin{array}{l}\text { GOGO } 1 \\
\text { (GEOSECS) } \\
\left(28^{\circ} 29^{\prime} \mathrm{N},\right. \\
\left.121^{\circ} 38^{\prime} \mathrm{W}\right) \\
\text { (off Baja } \\
\text { California) }\end{array}$} & $260-800$ & $\begin{array}{l}\left.\text { with } \mathrm{PO}_{4} \text { only: } \mathrm{O}_{2}=7.60 \pm 0.57\right)-(2.22 \pm 0.21) \mathrm{PO}_{4} \\
\left.\text { with } \mathrm{PO}_{4} \text { \& }: \mathrm{O}_{2}-(10.78 \pm 1.20)-(2.82 \pm 0.23) \mathrm{PO}_{4}-10.23 \pm 0.07\right) 0\end{array}$ & 0.090 & 5 \\
\hline & $1200-4200$ & $\begin{array}{l}\text { with } \mathrm{PO}_{4} \text { only: } O_{2}=(12.81 \pm 0.44)-(3.61 \pm 0.16) \mathrm{PO}_{4} \\
\text { with } \mathrm{PO}_{4} \& \theta: O_{2}=(11.50 \pm 1.54)-(3.05 \pm 0.66) \mathrm{PO}_{ \pm}-(0.19 \pm 0.21) \theta\end{array}$ & 0.994 & 16 \\
\hline & $905-2005$ & $\begin{array}{l}\text { with } \mathrm{NO}_{3} \text { only: } \mathrm{O}_{2}=(17.17 \pm 4.16)-(0.38 \pm 0.10) \mathrm{NO}_{3} \\
\text { with } \mathrm{NO}_{3} \& \theta: \mathrm{O}_{2}=(9.77 \pm 3.36)-\left(0.18 \pm 0.081 \mathrm{NO}_{3}-(0.36 \pm 0.14) \theta\right.\end{array}$ & 0.997 & $\begin{array}{l}5 \\
+\end{array}$ \\
\hline & $2005-4200$ & $\begin{array}{l}\text { with } \mathrm{NO}_{3} \text { unly: } O_{2}=(17.91 \pm 2.64)-(0.39 \pm 0.07) \mathrm{NO}_{3} \\
\text { with } \mathrm{NO}_{3} \& \theta: \mathrm{O}_{2}=(8.90 \pm 2.4)-(0.12 \pm 0.07) \mathrm{NO}_{3}-(1.19 \pm 0.28) \theta\end{array}$ & 0.992 & $\begin{array}{l}12 \\
11\end{array}$ \\
\hline \multirow{5}{*}{$\begin{array}{l}\text { ATLAN TIC } \\
\text { ST ATION } \\
\text { (GEOSECS) } \\
\left(35^{\circ} 46.0^{\prime} \mathrm{N},\right. \\
\left.67^{\circ} 58.0^{\prime} \mathrm{W}\right)\end{array}$} & $430-860$ & $\begin{array}{l}\text { with } \mathrm{PO}_{4} \text { only: } \mathrm{O}_{2}=(5.17 \pm 0.11)-(1.58 \pm 0.20) \mathrm{PO}_{4} \\
\text { with } \mathrm{PO}_{4} \& \mathrm{\theta}: \mathrm{O}_{2}=(8.52 \pm 3.84)-(2.72 \pm 1.31) \mathrm{PO}_{4}-(0.18 \pm 0.17) \theta\end{array}$ & 0.998 & $\begin{array}{l}4 \\
3\end{array}$ \\
\hline & $860-1840$ & $\begin{array}{l}\text { with } \mathrm{PO}_{4} \text { only: } O_{2}=(9.11 \pm 6.67)-(3.18 \pm 5.29) \mathrm{PO}_{4} \\
\text { with } \mathrm{PO}_{4} \& \mathrm{~A}: O_{2}=(10.49 \pm 0.74)-(2.62 \pm 0.53) \mathrm{PO}_{4}-(0.35 \pm 0.02) \mathrm{O}\end{array}$ & 0.993 & $\begin{array}{l}8 \\
7\end{array}$ \\
\hline & $150-580$ & $\begin{array}{l}\text { with } \mathrm{NO}_{3} \text { only: } O_{2}=(4.97 \pm 0.29)-\left(0.041 \pm 0.0591 \mathrm{NO}_{3}\right. \\
\text { with } \mathrm{NO}_{3} \& \theta: O_{2}=(11.09 \pm 3.44)-\left(0.18 \pm 0.081 \mathrm{NO}_{3}-(0.31 \pm 0.17) \theta\right.\end{array}$ & 0.905 & $\begin{array}{l}5 \\
+\end{array}$ \\
\hline & $860-1840$ & $\begin{array}{l}\text { with } \mathrm{NO}_{3} \text { only: } O_{2}=(12.18 \pm 5.75)-\left(0.36 \pm 0.28 \times \mathrm{NO}_{3}\right. \\
\text { with } \mathrm{NO}_{3} \& \theta: \mathrm{O}_{2}=(10.82 \pm 0.67)-(0.20 \pm 0.04) \mathrm{NO}_{3}-(0.30 \pm 0.03) \theta\end{array}$ & $\mid 0.995$ & $\begin{array}{l}8 \\
7\end{array}$ \\
\hline & $1840-4915$ & $\begin{array}{l}\text { with } \mathrm{NO}_{3} \text { only: } \mathrm{O}_{2}-(7.43 \pm 1.12)-(0.07 \pm 0.06) \mathrm{NO}_{3} \\
\text { with } \mathrm{NO}_{3} \& \mathrm{\theta}: \mathrm{O}_{2}-(4.26 \pm 1.54)-\left(0.16 \pm 0.081 \mathrm{NO}_{3}-10.11 \pm 0.08\right) 0\end{array}$ & 0.571 & 14 \\
\hline
\end{tabular}

* $n \rightarrow p-1$ are the residual degrees of freedom, $n$ is the number of observations and $p$ is the number of inclepentent variables already in the regression equation. 


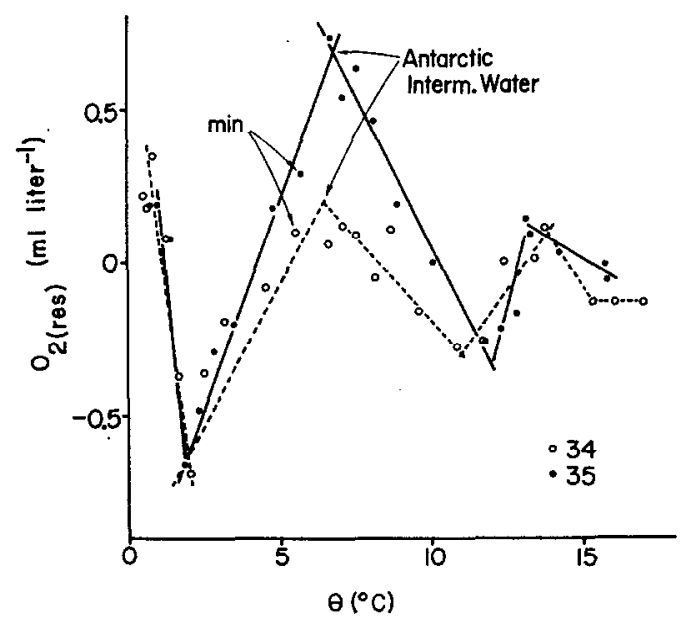

Fig. 9. $O_{2(r e s)}$ versus $\theta$ diagrams for the whole water column of stations 34 and 35 of the SOUTHERN CROSS cruise $\left(39^{\circ} 59.5^{\prime} \mathrm{S}, 170^{\circ} 03.2^{\prime} \mathrm{W}\right.$ and $42^{\circ} 01.2^{\prime} \mathrm{S}, 170^{\circ} 01.8^{\prime} \mathrm{W}$ ).

For station AAH2, in the southeastern Bering Sea, the presence of a temperature minimum and maximum in the upper 400 m (Alvarez-Borrego et al. 1972) made $S$ a better parameter than $\theta$ for the regressions; a higher coefficient of determination was obtained using $S$ instead of $\theta$ as the independent variable. At $\mathrm{HAH} 52$ the temperature minimum and maximum are also present but $\theta$ was used in the regression with satisfactory results (Table 3 ). In the Atlantic and South Pacific Oceans, changes of $\mathrm{O}_{2}, \mathrm{PO}_{4}$, and $\mathrm{NO}_{3}$ are not as great as in the North Pacific Ocean. When changes in these properties are small, random errors of the determinations are large in percentage. SCORPIO stations 71 and 72 are geographically close, $43^{\circ} 14.7^{\prime} \mathrm{S}, 80^{\circ} 02.0^{\prime} \mathrm{W}$, and $43^{\circ} 19.0^{\circ} \mathrm{S}, 79^{\circ} 01.5^{\prime} \mathrm{W}$, and were treated together to have more degrees of freedom for the regression.

With few exceptions, the results are consistent with Redfield's model (Tables 3 and 4). For SCORPIO stations 71 and 72 the $\mathrm{PO}_{4}$ regression coefficient is slightly higher than the value predicted by Redfield's model. The adjustment of the $\mathrm{NO}_{3}$ regression coefficient after $\theta$ was added to the equation was in the right direction, but

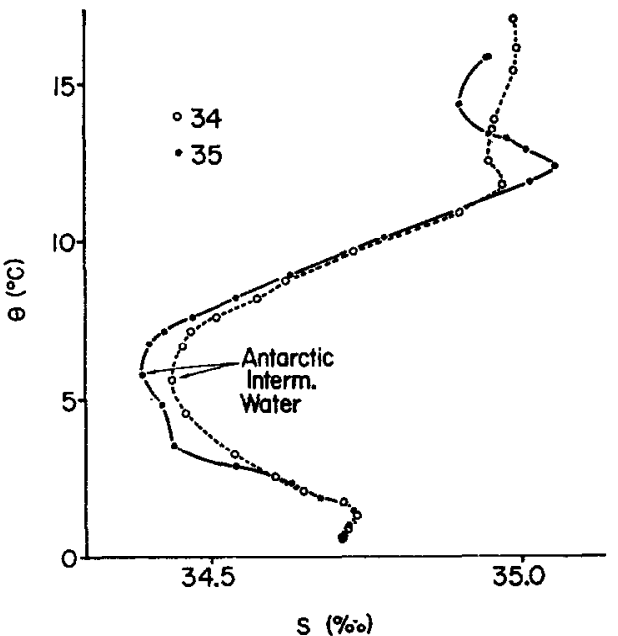

Fig. 10. $\theta-S$ diagrams for stations 34 and 35 of the SOUTHERN CROSS cruise.

it went too far (Table 3 ). In some cases the $\mathrm{PO}_{4}$ and $\mathrm{NO}_{3}$ regression coefficients were not significantly different from zero before $\theta$ was added to the equations, but they became consistent with Redfield's model when it was added (Tables 3 and 4 ).

The confidence interval for the $\mathrm{PO}_{4}$ regression coefficient after $\theta$ is added to the equation is $-4.21 \pm 1.14$ (Table 3 ) at station AAH2 $(1,215-3,200 \mathrm{~m})$. Alvarez-Borrego et al. (1972) applied regression analysis to the region of the water column where the $\theta-S$ diagram is straight $(1,300-3,600 \mathrm{~m})$. They treated data from stations AAH2 and AAH9 (also in the southeastern Bering Sea) together and obtained a $\mathrm{PO}_{4}$ regression coefficient of $-3.4 \pm 1.0$. The confidence interval in this case is larger because we have fewer degrees of freedom. Alvarez-Borrego et al. (1972) calculated $\mathrm{PO}_{4(p)}$ using Redfield's model, plotted it versus $\theta$ for the region of the water column where they applied the regression, and found a significant, although not very pronounced, departure from linearity. On this basis they indicated that their application of regression analysis to test Redfield's model was a first approximation. The $\mathrm{O}_{2(\mathrm{res})}-\theta$ diagram for the whole water column of station AAH2 does not detect the presence of a third water type for the depth range 1,215 


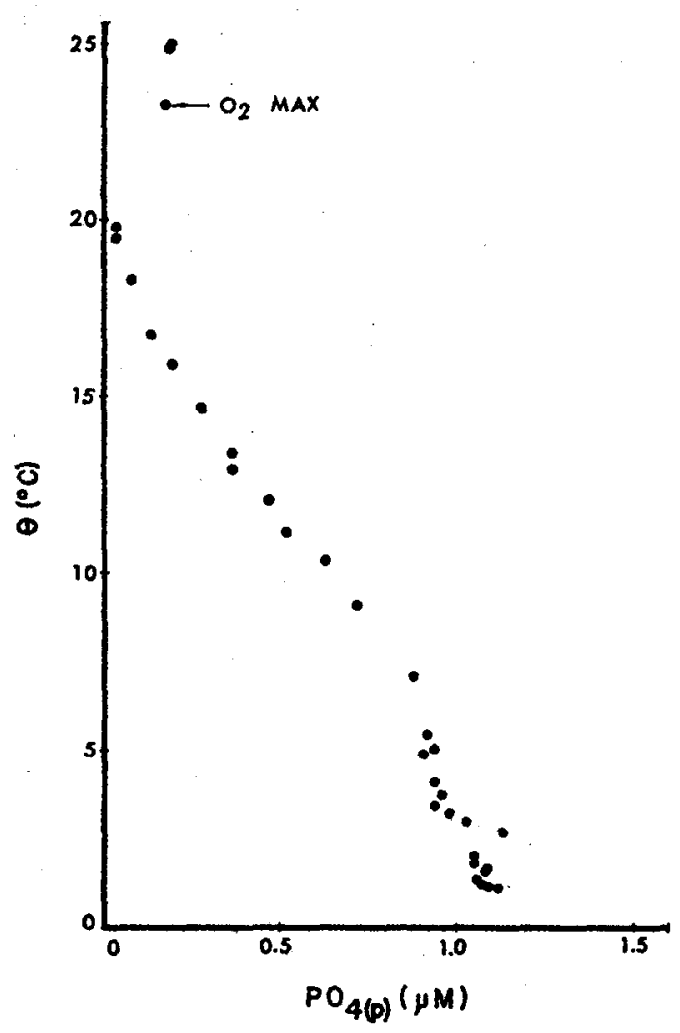

Fig. 11. $\theta$ versus $\mathrm{PO}_{((p)}$ diagram for station HAH $22\left(24^{\circ} 30.6^{\prime} \mathrm{N}, 161^{\circ} 30.0 \mathrm{~W}\right)$.

$3,200 \mathrm{~m}$ (not shown). The $\mathrm{O}_{2 \text { (ses) }}-\theta$ diagram can clearly detect different water types only when abrupt inflections in the $\mathrm{O}_{2}^{\prime}+a_{1} \mathrm{PO}_{4(p)}$ versus $\theta$ diagram exist. The confidence intervals obtained by AlvarezBorrego et al. (1972) and here are consistent with Redfield's model.

Proportion of water types-We used data from the SOUTHERN CROSS cruise (Horibe 1970) to test Redfield's model in the South Pacific Ocean. The ranges for $\mathrm{O}_{2}$, $\mathrm{PO}_{4}$, and $\theta$ are smaller than in the North Pacific Ocean and we did not obtain a significant regression when applying our method to data from one station. Because of this, we applied Eq. 9 to data from two stations simultaneously. The $\mathrm{O}_{2 \text { (ree) }}-\theta$ diagram (Fig. 9) shows that the proportions of the different water types are different at each station. We cannot represent data from both stations with the same set of re-



Fig. 12. $O$, versus PO, diagram for station HAH22.

gression equations. Figure 9 shows that when Eq. 9 has been applied to data from two geographically close stations, the $\mathrm{O}_{2 \text { (res) }}-\theta$ diagram may be used to indicate which station has a higher proportion of a certain water type. The $\mathrm{O}_{2 \text { (rea) }}-\theta$ diagram (Fig. 9) and the O-S diagram (Fig. 10) show that station 35 has a higher proportion of Antarctic Intermediate Water (station 35 is farther south than 34). The $\mathrm{O}_{2(\mathrm{res})}-\theta$ diagram does not give any differentiation for SCORPIO stations 71 and 72 (not shown).

Estimation of mixing-Station HAH22 has an almost linear $\mathrm{PO}_{4(\mathrm{p})}-\theta$ diagram for the region of the water column $(75-4,550$ $m$ ) below the near-surface $\mathrm{O}_{2}$ maximum (Fig. II). Its $\mathrm{O}_{2}{ }^{\prime}-\theta$ diagram is similar to that for HAH3O (Fig. 4). This allows us to illustrate the extraction of the mixing effect by adding a conservative property, such as $\theta$, to the regression equation. The $\mathrm{O}_{2}-\mathrm{PO}_{4}$ diagram for station $\mathrm{HAH} 22$ (Fig. 12) has a hooklike shape; if this is due to variation in the preformed quantities, $\theta$ should extract the mixing effect and leave a linear relationship between $\mathrm{O}_{2}$ and $\mathrm{PO}_{4}$. 


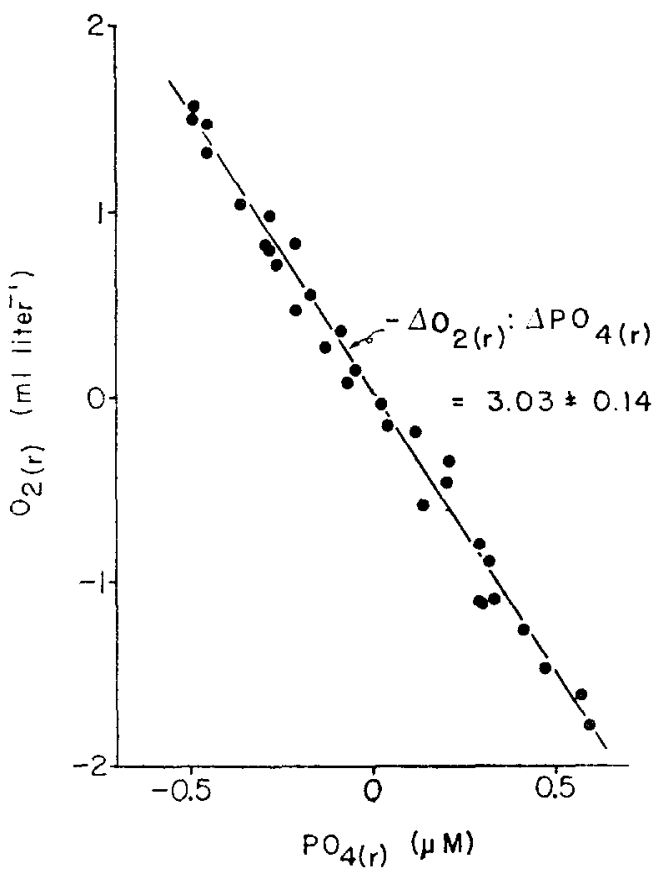

Fig. 1.3. Onr versus $\mathrm{PO}_{4(r)}$ diagram for station IIAII2?.

This is only a first approximation because the $\mathrm{O}_{2}^{\prime}-\theta$ and $\mathrm{P}^{\prime} \mathrm{O}_{\mathrm{H}_{1},}, \theta$ diagrams are not completely lincar.

When $\mathrm{O}_{3}$ is regressed on $\mathrm{PO}_{4}$ and $\theta$, the PO, term represents the regression of the residuals of $\mathrm{O}_{2}$ after regression on $\theta$. The residuals of $\mathrm{PO}_{4}$ which resulted from a simple lincar regression on $\theta$ are then fitted with $O$.rir. When we do the regression in a stepwise mamner, adding $\theta$ first, we have

$$
\mathrm{O}_{2}=c_{13}+c_{1} \theta+\mathrm{O}_{2(\mathrm{i})} \text {. }
$$

Implicitly and simultaneously

$$
\mathrm{PO}_{4}=d_{0}+d_{1} \theta+\mathrm{PO}_{4(\mathrm{r})},
$$

where $c_{m}, c_{1}, d_{0}$, and $d_{1}$ are constant regression coefficients and $\mathrm{O}_{2(r)}$ and $\mathrm{PO}_{4(n)}$ are the $O_{2}$ and $P O_{1}$ residuals after regression on $\theta$.

Aclding $\mathrm{PO}_{4}$ to regression Eq. 26, we regress $\mathrm{O}_{2(\mathrm{r})}$ on $\mathrm{PO}_{4(\mathrm{r})}$,

$$
\mathrm{O}_{2(n)}=f_{0}+a_{1} \mathrm{PO}_{4(\mathrm{r})}+\mathrm{O}_{2(\mathrm{rms})}
$$

where $f_{1}$ and $a_{1}$ are constant regression coofficients and $\mathrm{O}(n)$ is defined in Eq. 9 .
Substituting the value of $\mathrm{PO}_{4(\mathrm{r})}$ from 27 into 28 we have

$$
\begin{aligned}
\mathrm{O}_{2(1)}= & \left(f_{0}-a_{1} d_{0}\right)+a_{1} \mathrm{PO}_{4} \\
& -a_{1} d_{1} \theta+\mathrm{O}_{2(\text { res })},
\end{aligned}
$$

and substituting 29 into 26 we have

$$
\begin{aligned}
\mathrm{O}_{2}= & \left(c_{0}+f_{0}-a_{1} d_{0}\right)+a_{1} \mathrm{PO}_{4} \\
& +\left(c_{1}-a_{1} d_{1}\right) \theta+\mathrm{O}_{2 \text { (res) }} .
\end{aligned}
$$

The terms $\left(C_{0}+f_{0}-a_{1} d_{0}\right)$ and $\left(c_{1}-a_{1} d_{1}\right)$ are constants and can be represented by $a_{0}$ and $a_{2}$. Therefore, Eq. 30 is the same as 9 . The $\mathrm{PO}_{4}$ regression coefficient of Eq. 9, $a_{1}$, is the slope of the $\mathrm{O}_{2(\mathbf{r})}$ versus $\mathrm{PO}_{4(\mathbf{r})}$ diagram.

For station $\mathrm{HAH}_{22}$ the $\mathrm{O}_{2}-\mathrm{PO}_{4}, \mathrm{O}_{2}-\theta$, and $\mathrm{PO}_{4}-\theta$ correlation coefficients are -0.91, 0.75, and -0.95. Applying Eq. 26 and 27 we have

$$
\mathrm{O}_{2 .}=(1.68 \pm 0.56)+(0.18 \pm 0.06) \theta \text {, }
$$

and

$$
\mathrm{PO}_{4}=(3.19 \pm 0.18)-(0.16 \pm 0.02) \theta \text {. }
$$

Figure 13 shows the $\mathrm{O}_{2(r)}$ versus $\mathrm{PO}_{4(\mathrm{r})}$ diagram. The hooklike shape shown in Fig. 12 has disappeared after $\theta$ has extracted the mixing effect. The $\mathrm{O}_{2(r)}-\mathrm{PO}_{4(\mathrm{r})}$ correlation coefficient is -0.99 and the confidence interval for the $\mathrm{O}_{2(\mathrm{r})}-\mathrm{PO}_{4(\mathrm{r})}$ slope is $-3.03 \pm$ 0.14 , which is consistent with Redfield's model. In Fig. 13 the data points are not sequential with depth: points at onc end are not necessarily near-surface points, and points at the other end are not necessarily deep points. Data points at the lower end of the $\mathrm{O}_{2(r)}-\mathrm{PO}_{4(\mathrm{r})}$ diagram correspond to the $O .2$ minimum zone.

$\mathrm{O}_{2(\mathrm{r})}$ and $\mathrm{PO}_{4(\mathbf{r})}$ should not be regarded as nonconservative fractions of $\mathrm{O}_{2}$ and $\mathrm{PO}_{4}$. $\mathrm{O}_{2(x)}$ and $\mathrm{PO}_{4(\mathrm{r})}$ values by definition become zero when added. For this station the calculated ranges for $\mathrm{AOU}$ and $\mathrm{PO}_{4(0 x)}$ are 0.16 to $6.40 \mathrm{ml}$ liter $^{-1}$ and 0.05 to 2.05 $\mu \mathrm{M}$. The ranges for $\mathrm{O}_{2(n)}$ and $\mathrm{PO}_{4(\mathrm{r})}$ are only about half the ranges for $A O U$ and $\mathrm{PO}_{4(0 \times)}$ (Fig. 13) because $\mathrm{AOU}$ and $\mathrm{PO}_{4(o x)}$ are partially correlated with $\theta$. Thus, when we make the stepwise regression adding $\theta$ first as shown in Eq. 26, the $\theta$ term contains information about $\mathrm{O}_{2}{ }^{\prime}+$ 
$3.1 \mathrm{PO}_{4(\mathrm{p})}, \mathrm{AOU}$, and $\mathrm{PO}_{4(0 x)}$. The complete regression equation for HAH22 $(75-4,550 \mathrm{~m})$ is

$$
\begin{aligned}
\mathrm{O}_{2}= & (11.33 \pm 0.45)-(0.31 \pm 0.02) \theta \\
& -(3.03 \pm 0.14) \mathrm{PO}_{4}
\end{aligned}
$$

with a coefficient of determination $R^{2}=$ 0.994 .

In summary, our multiple regression analysis gave results consistent with values predicted by Redfield's model for $\Delta \mathrm{O}_{2}$ : $\Delta \mathrm{PO}_{4}$ and $\Delta \mathrm{O}_{2}: \Delta \mathrm{NO}_{3}$ ratios. Diagrams of $\mathrm{O}_{2}$ residuals after regression of $\mathrm{O}_{2}$ on $\theta$ and $\mathrm{PO}_{4}$ on $\theta$ or $\mathrm{NO}_{3}$ can be used to detect water types, some of which are not clearly shown by $\theta-S$ diagrams. Qualitative studies on the proportions of water types at different stations can also be done using the $\mathrm{O}_{2}$ residuals versus $\theta$ diagram.

\section{References}

Alvarez-Borrego, S., L. I. Gordon, L. B. Jones, P. K. PARK, AND R. M. Pytkawicz. 1972. Oxygen-carbon dioxide-nutrients relationships in the southeastern region of the Bering Sea. J. Oceanogr. Soc. Jap. 28: 71-93.

Barstow, D., W. Gilbert, K. Park, R. Still, and B. Wyatt. 1968. Hydrographic data from Oregon waters, 1966. Oregon State Univ. Dep. Oceanogr. Data Rep. 33. 109 p.
BeN-YAakov, S. 1971. A multivariable regerssion analysis of the vertical distribution of $\mathrm{TCO}_{2}$ in the Eastern Pacific. J. Ceophys. Res. 76: 7417-7431.

Fleming, R. H. 1941. The composition of plankton and units for reporting population and production. Proc. Pac. Sci. Congr. (6th) Calif., 19393 : 535-540.

Horibe, Y. [Ed.]. 1970. Preliminary report of the Hakuhō Maru Cruise KH-68-4 (SOUTHERN CROSS cruise). Ocean Res. Inst. Univ. Tokyo.

REDFieLd, A. C. 1934. On the proportions of organic derivatives in sea water and their relattion to the composition of plankton, p. 176 192. In James Johnstone Mem. Vol. Univ. Liverpool.

- 1942. The processes determining the concentration of oxygen, phosphate and other organic derivatives within the depths of the Atlantic Ocean. Pap. Phys. Oceanogr. Meteorol. 9(2): 22 p.

- B. H. Ketchum, and F. A. Richanus. 1963. The influence of organisms on the composition of seawater, p. 26-77. In M. N. Hill [ed.], The sea, v. 2. Interscience.

ReID, J. L. 1965. Intermediate waters of the Pacific Ocean. Johns Hopkins.

Spencer, D. W. 1970. GEOSECS intercalibration and test cruise. Woods Hole Occanogr. Inst. Tech. Rep. Ref. 70-63.

Submitted: 30 August 1973 Accepted: 8 May 1975 